\title{
Legal basis for the use of digital technologies for monitoring remote workers in the digital economy
}

\author{
Alexey Lada* \\ Far-East Institute of Management, Branch of RANEPA, 680000 Khabarovsk, Russia
}

\begin{abstract}
The article discusses the legal basis for the use of digital technologies in labor relations. Digital technologies can be used both in the performance of work, for example, the work of remote workers, and in the control of employees. When monitoring employees, including remote workers, the use of digital technologies and public information and telecommunications networks by the employer comes first. Moreover, the use of digital technologies by the employer when monitoring remote workers is the only means of control. The author examines the legal regulation of the implementation of such means of control over employees as video surveillance, an automated system for monitoring and recording working hours, monitoring sites that an employee visited from his office computer during working hours, checking correspondence in corporate email, listening to telephone conversations, using billing programs, and provides examples from court practice. The author identifies the defects of legal regulation in these areas and suggests ways to improve the legislation.
\end{abstract}

\section{Introduction}

During the period of the pandemic and self-isolation, the need for more extensive use of remote technologies in labor relations was revealed, in particular, the use of remote labor.

Thus, as scientists note, remote work and the employee in the remote access mode are becoming a normal practice today, which corresponds to the new relationship in the social and labor sphere and metaphysics (philosophy of law) (Lada \& Markov, 2019, p.2).

In the field of labor relations, foreign countries have long been using digital technologies. Thus, at the level of the European Union, a Framework Agreement on Teleworking has been concluded on issues related to the use of electronic homeworkers. In article 2 of this agreement specifies the definition of telework, according to which telework is one of the forms of organizing and (or) performing work, using information technologies, in the context of an employment contract (relationship), where work that can also be performed on the premises of the employer is carried out outside these premises on a regular basis.

Similar definitions of remote work are also enshrined in the legislation of the Republic of Kazakhstan (Article 138 of the Labor Code of the Republic of Kazakhstan), the Republic of Lithuania (Article 52 of the Labor Code of the Republic of Lithuania), the Republic of

\footnotetext{
*Corresponding author: alexlada@inbox.ru
} 
Moldova (Article 292-1 of the Labor Code of the Republic of Moldova), the Republic of Tajikistan (Article 255. Labor Code of the Republic of Tajikistan).

The widespread use of remote work has caused the need to improve the means of monitoring remote workers and its legal regulation. In this regard, these issues are currently relevant.

\section{Research methodology}

The study used the historical and legal method, the comparative legal method, the formal legal method, the logical method, and the methods of analysis and synthesis.

\section{Results and discussions}

In the Labor Code of the Russian Federation, remote work is fixed in Chapter 49.1 of the Labor Code of the Russian Federation. It should be noted that with the help of digital technologies, the Labor Code of the Russian Federation allows the possibility of concluding not only an employment contract with a remote employee, but also an apprenticeship contract. Prior to this, on the expediency of such a solution has been repeatedly pointed out in the scientific literature (Petrov \& Lada, 2020, p. 2362 ). However, in the legal literature, scientists pay attention to the fact that the law does not disclose or regulate the procedure for negotiating in electronic form an employment contract and an apprenticeship contract (Lada, 2020 , p.201 ). Also progressive is the introduction of electronic workbooks, the advantages of which are obvious, especially for remote workers (Lada, 2020, p. 924).

The Labor Code of the Russian Federation provides for the possibility of establishing remote work for any employee by agreement of the parties. The pre-emptive right to conclude an employment contract on remote work for certain categories of employees is not established. In this regard, it seems necessary to borrow the existing experience of foreign countries that have established the priority right to conclude an employment contract on remote work for certain categories of employees. Thus, in Article 52 of the Labor Code of the Republic of Lithuania, such a right is granted to pregnant women, women with children under three years of age, an employee raising a child under the age of fourteen or a disabled child under the age of eighteen, in Article 305 of the Labor Code of the Republic of Belarus, in relation to home work, such a right is granted to disabled and retired persons, persons with reduced working capacity, as well as persons caring for disabled or long-term ill family members who need care for health reasons.

In this regard, scientists propose to establish a preferential right to conclude an employment contract for remote work for women who have children under the age of 16, as well as disabled children under the age of 18, persons caring for disabled people, persons over 80 years old, long-term ill family members in need of care (Kozhevnikov \& Chudinovskikh, 2020, p.579).

It is necessary to agree with the opinion of scientists about the need to establish a preemptive right to conclude an employment contract for remote work for certain categories of employees. The pre-emptive right must be established for a pregnant woman, one of the parents (guardian, trustee) who has a child under the age of fourteen (a disabled child under the age of eighteen), as well as a person caring for a sick family member in accordance with a medical report issued in accordance with the procedure established by federal laws and other regulatory legal acts of the Russian Federation.

When monitoring employees, employers use digital technologies and public information and telecommunications networks. Scientists cite the example of a foreign company "Amazon", in which employees are dismissed automatically - based on the results of 
monitoring the performance of employees ' work duties using sensors and tracking systems, and the decision to dismiss is also made on the basis of algorithmic process management (Filippova, 2020, p. 169). Under Russian law, this is not allowed.

Often, employers install video surveillance of employees for the purpose of monitoring, and video surveillance data is used as evidence when bringing an employee to disciplinary responsibility. Judicial practice proceeds from the fact that the employer has the right to install video surveillance of employees only under the following conditions: video surveillance is carried out only for specific and predetermined legitimate purposes related to the performance of the employee's official (labor) duties, employees are informed about the conduct of video surveillance, video surveillance is conducted openly, in rooms where video cameras are installed, there are appropriate information signs in the areas of visibility of cameras. In this case, the video recording of the working process is not a disclosure of the employee's personal data and does not fall under Chapter 14 of the Labor Code of the Russian Federation "Protection of Employee's personal Data" (Ulyanovsk Regional Court, 2019, N 33-836).

In conjunction with this, the employer applies a system of control and accounting of working time (ACS), which allows you to record the time of arrival and departure of the employee. Such tools help to indirectly control the time spent by the employee at the workplace. The data from the turnstile for each magnetic card is usually stored on the server using special software. Also, the software can automatically take into account the time worked by the employee within his working schedule, calculate the hours of work charged differently, which allows it to be used not only to monitor the discipline of the employee, but also to keep track of working time. The system of control and accounting of working hours (ACS) is also used to suspend an employee from work on the grounds provided for in Article 76 of the Labor Code of the Russian Federation.

However, as scientists note, this will not replace keeping a timesheet on paper. More advanced electronic systems allow you to create a timesheet according to the forms N T-12 and T-13, but you still need to print it out and sign it every month (Ivleva, 2015.).

The courts accept as evidence printouts from the electronic system of control and accounting of working time (Sverdlovsk Regional Court, 2012, N 33-6191), sometimes even as the only evidence in the case (Moscow City Court, 2018, N 33-8775), but provided that the use of the electronic system of control and accounting of working time is recorded in the local regulations of the organization, with which the employee was acquainted, otherwise the court may not accept such data as evidence (Khabarovsk Regional Court, 2012, N 33-5779).

For the most part, the courts use printouts from the electronic system of control and accounting of working hours only in conjunction with other evidence - acts, memos, witness statements, timesheets. In addition, the data of the electronic system for monitoring and recording working hours can be discredited by its frequent failures or by the fact that, in general, an employee can get to his workplace and leave it, bypassing this system (Voronezh Regional Court, 2017, No. 33-6873).

An electronic system for monitoring and recording working hours will allow for disciplinary action against smokers. An actual situation is when an employee leaves the workplace for smoking. During the day, the amount of time spent smoking can be significant. Therefore, in some organizations, with the help of video surveillance and an electronic system for monitoring and recording working hours, they began to record the time when an employee was absent for smoking, deduct this time from working time and do not pay it to the employee.

An employee may be at the workplace all day, but may not perform their work function. To do this, employers use other technical means, in particular, monitoring the sites that the employee visited from his office computer during working hours, checking the correspondence in the corporate email. 
The courts recognize that it is lawful for the employer to check correspondence from corporate e-mail and use this information as evidence in the case (The Supreme Court of the Republic of Bashkortostan, 2015, No.33-17852). At the same time, scientists also express their opinion about the legality of tracking correspondence from personal mail, but from a work computer when using extracts from the computer activity tracking system and Internet traffic as evidence, which allow you to record the addresses at which the network was accessed (Slesarev ,2016).

The courts also recognize that it is lawful for the employer to check the sites that the employee visited during working hours from the work computer and to use the browser log inspection report as evidence in the case (Ryazan Regional Court, 2015, No.33-335).

In these cases, the employer must adopt a local regulatory act on the control of the employee and obtain his written consent to this. Otherwise, this information can not be used in court as evidence. The need for the employer to adopt a special local regulatory act on the control of the employee as a special measure for the introduction of a special legal regime was pointed out by the Constitutional Court of the Russian Federation in its Decision No. 25 P of October 26, 2017.

The issue of the possibility of the employer listening to the employee's telephone conversations during working hours when using an internal PBX or a service cell phone with the employer's SIM card is debatable. Supporters of the legality of wiretapping refer to the prohibition of an employee to conduct personal telephone conversations during working hours and the ownership of telephone sets with a SIM card to the employer. Opponents point to the secrecy of telephone conversations and personal or family secrets guaranteed in the Constitution of the Russian Federation. Thus, it is necessary to agree with scientists who believe that the employer does not have the right to insist on the employee signing an agreement on listening to negotiations, and if such an agreement is concluded, then it will not have legal force (Dvoretsky, 2009).

What tools can be used to monitor remote workers? The provisions of Article 292.3 of the Labor Code of the Republic of Moldova are considered progressive, according to which an employment contract with a remote employee must contain a condition on the work schedule, within which the employer has the right to check the employee's activities, and the method of control.

The installation of video surveillance can not be used to monitor a remote employee, since the employee performs a work function at home or elsewhere, and video surveillance would violate the legislation on the protection of personal data of the employee. In this regard, many programs, such as Microsoft Teams, even set a special background so as not to see the room in which the user works during a video conference.

Therefore, the employer tries to control the employees by calling the employee on the office phone. Changes in the Labor Code of the Russian Federation allow you to call an employee only during working hours. Some authors consider the obligation of an employee to be in touch (to keep a mobile phone on) during the working day to be legally controversial, if this phone (SIM card) is not provided by the employer or the employer does not compensate for mobile communication (Neretina, 2020, p.145). In addition, by giving the employee a service SIM card, the employer is able to know the location of the employee.

You can control a remote employee by using billing programs that record and synchronize the time spent by the user on a particular type of work, for example, Apple software that allows you to track the cursor movements on the remote employee's computer.If the cursor does not move for a certain time, a message is sent to the remote employee. To respond to such a message, the employee is given a certain time, if there is no response, the webcam turns on, and the employee receives a call (Leskina, 2018, p. 128 )

Most scientists consider it legitimate to establish such control programs. In support of their position, they refer to the fact that the norms of the Labor Code of the Russian 
Federation allow the use of software and hardware for any purpose, including for the purpose of monitoring the employee if there is a corresponding condition in the employment contract and providing the employee with appropriate equipment, including a computer, and software (Shcherbakova, 2020). Scientists also refer to the experience of foreign countries, where they actively develop and apply technical means of labor control (Leskina, 2018, p. 128).

If the employer does not provide the employee with equipment and the employee uses a personal computer for work purposes, then, according to some scientists, the employer does not have the right to require the employee to install programs on it to monitor the employee. This is due to the fact that programs for monitoring the employee on the employee's personal computer allow the employer to obtain the employee's personal information stored in the computer (Shcherbakova, 2020).

\section{Conclusion}

1. One of the manifestations of digitalization is the legal regulation of remote work, which not only involves the performance of a labor function through public Internet networks, but also interaction with the employer in electronic form.

2. Russian legislation does not provide for certain categories of employees a preferential right to conclude a contract on remote work, unlike the legislation of some foreign countries. In this regard, it is necessary to amend Article 312.1 of the Labor Code of the Russian Federation as follows: "The preferential right to conclude an employment contract for remote work is granted to: a pregnant woman, one of the parents (guardian, trustee) who has a child under the age of fourteen (a disabled child under the age of eighteen), as well as a person caring for a sick family member in accordance with a medical report issued in accordance with federal laws and other regulatory legal acts of the Russian Federation."

3. The employer has the right to control the performance of the employee's work function by any legal means, including monitoring the use of office equipment, corporate mail. At the same time, he is obliged to adopt a local regulatory act and notify the employee about the ways to exercise control over it.

4. Monitoring of remote workers must be carried out in conditions that do not violate their rights to the processing of personal data. In the Labor Code of the Russian Federation, there is no legal regulation of ways to control employees. In this regard, the employer fixes them in local regulatory legal acts, often establishing such illegal methods as wiretapping the employee's telephone conversations. In this regard, it is necessary to list the legal ways of controlling employees at the level of by-laws.

5. If an employer wants to monitor a remote employee, they should provide their own equipment, since tracking programs cannot be installed on the employee's equipment, as this would violate the legislation on the protection of personal data.

\section{References}

1. A. Lada, S. Markov, SHS Web of Conferences 72, 1 (2019)

2. A.Y. Petrov, A.S. Lada, Proceedings of the International Scientific Conference "Far East Con" (ISCFEC 2020), Published by Atlantis Press SARL. Part of series AEBMR 128, 2358 (2020)

3. A.S. Lada, International Conference on Finance, Entrepreneurship and Technologies in Digital Economy European (FETDE 2020), European Proceedings of Social and Behavioural Sciences EpSBS, 103, 198 (2020)

4. A.S. Lada, Proceedings of the 2nd International Scientific and Practical Conference "Modern Management Trends and the Digital Economy: from Regional Development to 
Global Economic Growth” (MTDE 2020), Published by Atlantis Press SARL. Part of series AEBMR 138, 923 (2020)

5. O.A. Kozhevnikov, M.V. Chudinovskikh, Vestnik St. Petersburg State University. Right. 11 (3), 563 (2020)

6. I.A. Filippova, Right. J. of the Higher School of Economics 2, 162 (2020)

7. Ulyanovsk Regional Court Appeal ruling, 33-836, (2019)

8. Yu. Ivleva, The Power of Time: how to use the electronic access control system, Main book, 11, (2015)

9. Sverdlovsk regional Court Definition, 33-6191, (2012)

10. Moscow City Court Appeal ruling, 33-8775, (2018)

11. Khabarovsk Regional Court Appeal ruling, 33-5779, (2012)

12. Voronezh Regional Court Appeal ruling, 33-6873, (2017)

13. Supreme Court of the Republic of Bashkortostan Appeal ruling, 33-17852, (2015)

14. S. Slesarev Surveillance of employees, or when the court recognizes video surveillance in the office and reading employees e-mails as legal, Information and legal portal Garant RU, (2016)

15. Ryazan Regional Court Appeal ruling, 33-335, (2015)

16. V.R. Dvoretsky Employers 'wiretapping of employees' telephone conversations: is it legal?, HR-Portal (2007)

17. A. Neretina, HR manager, 12. 143-149, (2020)

18. E.I. Leskina, Russian Law J., 4 (121), 125 (2018)

19. O.V. Shcherbakov, HR manager, 12, (2020) 